\title{
Toward a General Theory of Institutional Autonomy*
}

\author{
Seth Abrutyn \\ University of California, Riverside
}

Published in Sociological Theory

Citation:

Abrutyn, Seth. 2009. "Toward a General Theory of Institutional Autonomy." Sociological Theory 27(4):449-465.

*I would like to thank Jonathan Turner, Steven Brint, Kirk Lawrence, Richard Niemeyer, and Kristopher Proctor for their comments and suggestions on earlier drafts. 


\begin{abstract}
Institutional differentiation has been one of the central concerns of sociology since the days of Auguste Comte. However, the overarching tendency among institutionalists like Durkheim or Spencer has been to treat the process of differentiation from a macro, 'outside in' perspective. Missing from this analysis is how institutional differentiation occurs from the 'inside out', or through the efforts and struggles of individual and corporate actors. Despite the recent efforts of the "new institutionalism" to fill in this gap, a closer look at the literature will uncover the fact that (a) they have tended to conflate macro-level institutions and meso-level organizations and (b) this has led to a taken for granted approach to institutional dynamics. This paper seeks to develop a general theory of institutional autonomy; autonomy is a function of the degree to which specialized corporate units are structurally and symbolically independent of other corporate units. It is argued herein that the process by which these 'institutional entrepreneurs' become independent can explain how institutions become differentiated from the 'inside out'. Moreover, this paper offers five dimensions that can be operationalized, measuring the degree to which institutions are autonomous.
\end{abstract}




\section{INTRODUCTION}

If there is one time-tested truism in sociology, it has to be the fact that as societies gets larger, its parts begin to differentiate—i.e., resource niches (Hawley 1986), formal organizations (Blau 1970), groups and subcultures (Homans 1950), and status positions (Fried 1967), roles (R. H. Turner 2001) and identities (Stryker 1980). However, what concerns us here is the social phenomena most central to any study of society, which, according to Durkheim (1895), is the institution. Indeed, a cursory review of the classical canon (e.g., Comte [1851-4] 1968; Durkheim 1893; Spencer 1874-96; Weber 1978) as well as some contemporary schools such as the functionalist (Eisenstadt 1964; Parsons 1951), neo-functionalist (Alexander and Colomy 1990), and the systems approach (Luhmann 1982, 1984) will demonstrate the centrality and import afforded institutional differentiation—-both as a process of social change and an understanding of the effects of modernity. However, little has been said regarding how and why institutions develop from the "inside out," or from the efforts and struggles of real actors; rather, the focus has tended to be from the top down, assuming that environmental exigencies drive differentiation (see Sanderson 2007 for a general review). ${ }^{a}$ How and why institutions differentiate is further complicated by the emergence and growing pervasiveness of New Institutionalism (Nee 2005; Powell and DiMaggio 1991), which has all but ignored the question of institutional differentiation, choosing instead to examine organizational dynamics. Thus, it is proposed that by looking at the processes of institutional differentiation from the inside out it is possible to arrive at a more satisfying explanation of institutional growth in size and complexity. This paper's goal, then, is to revisit the classic tradition of institutional analysis and return it to its central position in sociological 
theory, while also providing a more robust environment and context in which to understand the contributions offered by New Institutionalism. This goal will be accomplished by delineating what institutions are, how they become autonomous, and how we can measure the growth and decline in institutional autonomy, ultimately providing a link between the macro world of the classic tradition and the meso world of New Institutionalism.

\section{Selecting Elements from the Classic Tradition}

Admittedly, the synthesis offered below finds itself closer to the classical functionalist and system theories traditions. For example, the definition offered below for institutions will be derived from the writings of theorists such as Spencer and Durkheim, but within the framework of the recently revived and reconsidered evolutionary school of sociology (i.e., Lenski 2005). This tradition begins with the assumption that institutions are macro in nature - that is, they organize a myriad of organizational and individual actors, symbolic systems, resources, and various rulesanctions sets. Moreover, institutions will be conceptualized as adaptive solutions to environmental exigencies - though, it should be noted, institutions are not always successful long-term adaptations. This paper also recognizes selection pressures - or pressures compelling individuals and societies to adapt or collapse-as the primary mechanism facilitating socio-cultural evolution. Thus, Turner (2003) notes that in the face of universal problems such as population pressures or inter-societal conflict, societies search for solutions; if successful, these solutions become institutionalized and eventually grow larger as new problems or new innovations are added (cf. Diamond 2004). 
Third, the central focus of this paper and the institutional dynamic considered to be key, the process of institutional autonomy, is derived from Parsons and Smelser (1956) — though they only mention it in passing. What can be deduced from the authors' argument is that institutions not only differentiate, but they also become autonomous, apparently by creating discrete boundaries between one institution and all others. Luhmann (1984) did attempt to elaborate this concept, arguing that autonomy has to do, in part, with the emergence of self-reflexivity. Essentially, Luhmann is concerned with the interaction system as the basic unit of analysis, noting that in communicative action, autonomy is revealed, reproduced, and altered. However, like Parsons, he leaves the concept 'institutional autonomy' undefined and generally ambiguous, but its import is never mistaken. Thus, the task of developing this concept has been generally ignored, but will begin to be corrected in the theoretical analysis below.

\section{Insights From New Institutionalism}

Unfortunately, little in the way of institutional dynamics can be derived from this tradition. It is argued here that New Institutionalism should perhaps be relabeled 'New Organizationalism' on account of the fact that what an institution is and how it develops is typically taken for granted, as the primary focus has been the organization and its dynamics within the "institutional environment." Even worse, some New Institutionalists conflate organizations and institutions, essentially defining them as one and the same (i.e., Jepperson 1991; Meyer and Rowan 1977; North 1990). To conflating the two social phenomena is to assume they are not distinct concepts, but in reality, organizations and institutions should be and are as discrete as atoms and molecules; a science of society must recognize and treat them as such. This criticism, however, should not be taken to 
imply that New Institutionalism has no value and should be abandoned. Quite the contrary: if we distinguish between organizations and institutions, then the classic tradition and New Institutionalism can survive side-by-side, supplementing each other by focusing on the macro and meso levels respectively.

Thus, a general theory of institutional autonomy can borrow and integrate some of the organizational dynamics elucidated by the empirical studies conducted by the New Institutional school (e.g., Dobbin and Sutton 1998; Sutton and Dobbin 1996) and the theoretical discussions that begin to look at institutions from the bottom up (or from the point of view of the corporate unit) (Edelman and Suchman 1997; Scott 2001). These studies offer a theory of institutional autonomy evidence and explanation denoting the ways in which organizations adapt and attempt to alter their environment in the face of external pressures and exigencies. Second, New Institutionalism provides other strong theoretical contributions in the way of inter-organizational interaction (DiMaggio 1991; DiMaggio and Powell 1983). And while this school is primarily focused on the formal economic organization in twentieth century U.S., the author believes it possible to generalize many of this school's insights to all corporate units-i.e., small groups or families — regardless of time or place, which would expand the reach and applicability of New Institutionalism.

\section{Overall Goal}

It is proposed that a general theory of institutional autonomy will be able to synthesize some of the insights of the classic functionalist/systems theory tradition of institutional analysis with those of New Institutionalism. It was argued that both provide insufficient solutions to the problem of institutional differentiation, but integrated, the 
two traditions will offer a more robust theory explaining how and why institutions differentiate while supplementing both theories. In turn, this synthesis will offer New Institutionalism a more robust understanding of the institutional environment in which their organizational dynamics play out, while also speaking to the classic tradition by explaining how differentiation works from the 'inside out', complementing their focus on the process from the 'outside in'. This theoretical analysis will begin by delineating the process of institutional autonomy, which involves corporate actors acting and reacting to their environment, thus linking the macro and meso levels of analysis. Essentially, it is argued that certain corporate units, historically, can monopolize valued resources associated with the production and distribution of certain universal human concerns, leading to their indispensability. With the growth of their indispensability, the possibility that they can become structurally and symbolically independent in their activities and knowledge becomes real. Finally, it is posited that the greater is the degree to which specialized corporate actors are structurally and symbolically independent, the greater is the degree to which the institution they are embedded within becomes autonomous.

However, before explaining institutional autonomy, the first task will be to clearly define 'institutions.' After defining institutions, our focus will be shifted to institutional autonomy; in the second section of the paper, a formal definition of autonomy will be offered as will an elucidation of the macro evolutionary forces compelling action of the meso level. Once defined and embedded within an historical context, the final section of the paper will examine how institutional autonomy increases and decreases over time and place by denoting the dimensions that can be used to measure autonomy. 


\section{DEFINING INSTITUTIONS}

Institutions are the building blocks of all societies; six macro institutions appear to be universal across time and space: kinship (Fox 1967; Levi-Strauss 1969), polity (Service 1975), religion (Goode 1951; Service 1971), economy (Polanyi 1944), law (Malinowski 1959; Weber 1967), and education (Brint [1998] 2006; Collins 1979). More recently, five macro institutions have become highly differentiated (and in some cases autonomous) in many industrial and post-industrial societies: medicine (Starr 1982), media (Luhmann 2000b), science (Popper [1934] 2002), art (Luhmann 2000a), and perhaps sports. ${ }^{\text {b }}$ For my purposes institutions will be defined as relatively enduring macro social structures that are adaptations to exigencies faced by all societies, producing a structural and cultural context facilitating and constraining corporate and individual actors through the uneven occupation of horizontal and vertical positions and the uneven distribution of material and symbolic resources. ${ }^{c}$ Institutional autonomy, then, is the state in and process by which institutions develop distinct structural and symbolic boundaries distinguishing them from other institutional domains. ${ }^{\mathrm{d}}$

The following discussion will unpack the definition offered above, element by element, in order to more clearly elucidate what an institution is and how autonomy, as an institutional dynamic, affects each element. To illustrate these abstract points more clearly, examples of the legal institution will be provided. While it would be more desirable to discuss in detail, each institution, but this would require a different format. Rather, law provides an interesting case because the general evolution of legal autonomy has been much more recent (Berman 1983; Unger 1976) than other institutions such as the polity (Eisenstadt 1963; Service 1975) or religious institution (Eisenstadt 1986). 
Moreover, legal autonomy is very tenuous, even where it appears most secure (Englard 1974; Irons 1999), thus it can provide clear examples of the variable nature of institutional autonomy.

\section{Institutions as Adaptive Structures}

The first element of institutions posited above, is that they are "macro social structures that are adaptations to exigencies faced by all societies.” If there are six universal institutions, then it should be implied that the types of exigencies causing institutions to develop are universal as well. These exigencies can be endogenous — such as resource scarcity (Boserup 1965), population pressures (Malthus [1798] 1926), or crises that produce problems of meaning (Weber 1922) — or exogenous — such as climatic change (Fagan 2004) or inter-societal conflict (Gat 2006). These problems produce selection pressures, which in turn, cause individuals and corporate units to make choices_-sometimes consciously, sometimes unconsciously_that, when aggregated, lead to the successful reduction of selection pressures and growth in institutional domains, or failure and the potential weakening of the society (Johnson and Earle 2000).

Using law to undergird this discussion, we must first answer why law existswhat types of historical exigencies lead to the emergence and growth of a legal institution that is an adaptation to these environmental problems? The answer to this question, admittedly, is complicated, but can be summarized to make the overarching point: based

on anthropological, archaeological, and sociological evidence, law appears to, in its most nascent and complex forms, deal with problems of conflict resolution and notions of justice (see, for example, Bohannan 1967; Gluckman 1965; Hoebel 1973; Malinowski 1959). It is proposed, then, that the greater the degree to which a legal institution is 
autonomous, the greater the degree to which it is the sole institution addressing questions of internal societal conflict and justice. However, in its infancy law lacks autonomyinseparable first from the kinship institution that dominate hunter/gatherer life (Maryanski and Turner 1992; Service 1962) and then, later, it comes to be deeply intertwined with the political and religious institutions (Berman 1983). With population growth and density, economic growth and increased rates of social exchange, and the heterogeneity typical of civilizations and empires, law becomes an increasingly autonomous institution easing disintegrative (selection) pressures by providing a nonviolent arena for conflict resolution (Black 1976). Thus the more effective the legal system is, the more a society can adapt to internal conflict, regulate exchanges in an orderly and non-violent manner, and acculturate different categoric units—or the various diffuse groups categorized by different markers such as ethnicity, gender, or occupation — and the more likely a legal institution, and especially its constituent actors, will be become autonomous.

The former Soviet Union provides a recent example demonstrating the importance of law, regardless of its level of autonomy. In the early stages of statecraft, Lenin ([1917] 1976) and his colleagues felt law, being part of the superstructure, was a capitalist institution built solely to protect property which they sought to abolish. The consequences of this decision resulted in confusion, uncertainty in economic and social transactions, and ultimately, the “discovery” of so-called ‘socialist law' which was essentially western law with a few additions and subtractions (Berman 1955). It is in the negative case, the case that illustrates a society's attempt at erasing the legal institution from the institutional complex, that the universality of the above institutions becomes 
clear: law is an adaptation to problems vexing all societies, and while the variation in what becomes legal, who decides what is legal, and how conflict is adjudicated is important, it is the universality of law that most defines its adaptive qualities. If institutions, then, are macro structures reflecting adaptive solutions to selection pressures, what exactly is adapting?

\section{Social Actors}

Social actors are composed of two kinds: individuals occupying roles and statuses and corporate units occupying resource niches (Hannan and Freeman 1977) or organizational fields (DiMaggio and Powell 1983). Institutions are the structural and cultural contexts in which these actors find meaning to theirs and other's actions and attitudes; the arenas in which actors struggle and compete for access to resources; and the "storehouse" of resources that orient action by providing the types of goals toward which people strive, the potential means with which to pursue these goals and interests, and the mechanisms of social control that constrain their behavior and others.

Moreover, institutions are the paramount structures facilitating and constraining actors. Two key elements facilitate and constrain social actors within institutions: the positions they have access to and the resources that guide their behavior. Both positions and resources have a three-fold function: (1) they provide the blueprints for action, interaction, goal-setting, and decision-making; (2) they provide the material for constructing a system of authority that is both affords some actors more freedom in their actions than others - which accounts for both innovation and rigidification; (3) they are mechanisms of social control. 
Horizontal and Vertical Positions. The definition posited above denotes two types of positions: horizontal positions, which are related to the division of economic and social labor and vertical positions, which are related to access to institutional resources, their production and distribution, as well as their consumption. Individual actors find themselves both in roles and status positions, which are the interstices of horizontal and vertical positions respectively. These roles and statuses reflect prior actors' selection, repeated interaction, and the subsequent institutionalization of these positions. Once institutionalized, new actors can occupy these positions. Without a doubt, the more status the role-player has, the greater is the degree of freedom they have to play their role as well as potentially re-make their role (Michels [1911] 1962).

Corporate units, which are located in institutional resource niches, are distributed horizontally and vertically as well. The more robust the resource niche, the greater the advantage the corporate unit has. Moreover, there is a vertical and horizontal distribution within resource niches: some corporate units in the same niche have better access to the resources inside the niche. For example, some law schools are more prestigious that others: they have access to the best students, their alumni contribute more, and their students have access to better jobs and networks. This determination is not static: law schools compete with each other and their upward and downward mobility is an annual event. ${ }^{\mathrm{e}}$

Actors and Autonomy. Simply put, the greater the degree to which an institution is autonomous, the greater the degree to which the horizontal and vertical positionsboth individual and corporate — will be discrete. Lawyers, judges, and clients become role and status positions unique to autonomous legal systems, as do law schools, law 
offices, and courthouses. While the emergence of a legal profession has its roots in ancient states such as Mesopotamia (Postgate 2003) and China (Chang 1983), an independent legal profession—one devoted to the problems, intellectual endeavors, and development of judicial questions (Weber 1967)—does not begin to appear until Rome (Harries 1999; Kunkel 1966), with its full expression emerging out of the early European universities (Berman 1983). ${ }^{\mathrm{f}}$ Implicitly, then, selection criteria for access to role positions and resource niches becomes more and more governed by legal actors and associations; the behaviors, goals, and decision-making processes of individual and corporate actors filling these positions become embedded and reproduced within the themes and texts of the legal institution (Luhmann 2004); and a corporate group gains a monopoly over the legitimate authority to develop, apply, disseminate, and transmit its practices and knowledge (Freidson 1994).

It must be remembered, though, that autonomy is a variable, reversible process; the variability of autonomy can be demonstrated by taking a cursory look at contemporary legal systems. In Iran, for example, lawyers and jurists are selected and act in accordance with the Koran and religious principles first and legal principles secondlegal action continues to be framed in terms of morality rather than justice (Akhavi 1992; Schirazi 1997); the former Soviet Union mirrors modern Iran in that the legal system was lacking autonomy and, as such, lawyers and judges oriented their actions towards the polity and party loyalty first and ideals of justice second (Berman 1968); compare these examples to either the contemporary United States (Chayes 1988) or Israel (Baker 1968; Barak 2000), where lawyers and jurists, by constitutional decree, are independent, are selected through particular legal criteria, are trained in legal universities devoted to the 
resolution of conflict and the establishment of justice, and who orient their behavior in legalistic ways more often than other ways (Carlin 1980; Hirschfield 1965). ${ }^{\mathrm{g}}$

\section{Material and Symbolic Resources}

Institutions are also comprised of material and symbolic resources that are selected from the larger socio-cultural warehouse (Giddens 1984; Swidler 1986). General resources include power, prestige, and wealth; all of which are both the goals that define actors' interests as well as the means to achieving these goals (Parsons 1990; Weber 1978). Other resources, however, play important roles in shaping the behavior, goals, and decisions of individual and corporate actors. Material resources, such as the instruments or tools needed to reproduce institutional roles, uniforms or emblems that define the role-player, and buildings that differentiate the physical and temporal space all act as resources that are used in the reproduction of institutional life (Goffman 1961). Less tangibly, patterned actions and scripts, institutional norms, and other modes of behavior are resources that simplify interaction, thus ensuring its regular success, while also constraining the actors ability to infinitely innovate (Goffman 1959).

Symbolic resources include value sets providing preference hierarchies, notions of good and bad, right and wrong; ideologies that explain present events, justify past events, and orient actors to the future; totems that define the sacred elements of institutional life (Douglas 1970); texts and themes, both of which naturally limit the types and styles of interaction by selecting some forms of language/interaction and ignoring others (Luhmann 1984); and finally, some symbolic generalized medium of exchange that allows institutional actors to exchange with each other, over great social and geographical distance, as well as with non-institutional actors (Parsons 1951; Simmel 1907). ${ }^{\text {h }}$ All of 
these resources facilitate behavior because they are the cultural "tools" necessary for reproduction of institutional operations as well as the things that people strive for; they are also constraining factors because some resources are selected from the environment, and others are not: this means that some resources are available and others are not. Moreover, some resources must be procured from other institutions-i.e., all institutions must seek material subsistence from the economy (Parsons and Smelser 1956)—which necessarily limits their authority and independence.

Resources and Autonomy. In terms of institutional autonomy, it is proposed that the greater the degree to which an institution is autonomous, the greater is the degree to which certain material and symbolic resources will be institutionally distinct. Again, legal institutions can provide some concrete illustrations. As the legal institution becomes autonomous, the texts and themes (Luhmann 2004), the methods, explanations, justifications, and orientations of legal actors (Unger 1976), and the buildings, uniforms, and symbology become distinct and recognizable by most members of society as being "legal resources." For instance, in the United States the robe and gavel come to represent the judge as a generalizable role; the Constitution and Bill of Rights come to symbolize the "rule of law;" and images like "blind lady justice" and "scales" come to represent the ideal of justice.

In less autonomous legal institutions, these symbols, themes, and buildings are less clearly delineated. In ancient Mesopotamia, for example, cases were adjudicated either in the palace, the temple, or before the local neighborhood assembly (Postgate 2003); moreover, legal “codes," such as the famous dictate of Hammurabi, are symbols of the divine right to kingship and not guidelines or instructions for jurists (Yoffee 2005); 
and finally, in most of the dynasties—except during the dominance of Babylon (2000 B.C.E.) - there were no professional judges, but rather ephemeral roles that were sometimes filled by priests, other times by elders or local governors, and still other times filled by the king himself (Potts 1997; Tadmor 1986). With the Rome and then the medieval church, lawyers and jurists became increasingly distinct, full-time actors concerned with law and not so much religious or political matters (Berman 1983).

\section{THE ORIGINS OF INSTITUTIONAL AUTONOMY}

Institutional autonomy is a sociocultural evolutionary process; as such, the conditions that propel institutional autonomy can be delineated. These conditions are general forces that appear to exist in all societies and are necessary for the differentiation and autonomy of institutions. As noted above, other conditions are socially and historically specific, and as such, would require a different formal of explication. These more specific elements should not be seen as any less important, but rather produce the intricacies and nuances of everyday social life that a general theory can rarely capture.

Macro Dynamics. The most basic force preventing or facilitating institutional development is population growth and density or the lack thereof. Without this initial force, selection pressures stemming from resource production and distribution or conflict are not likely to emerge. As such, nearly $95 \%$ of all humans have lived in small huntergatherer groups, governed by kinship organization (Service 1962). However, as population increases, resource scarcity becomes salient and solutions, most typically segmentation, are sought.

Societal fission is an acceptable solution only where space is plentiful. When societies become geographically and/or militarily circumscribed, population pressures 
become real exigencies that require socio-cultural innovation and not instinctual segmentation (Carneiro 1970). The earliest solutions to population pressures and geographic circumscription are the elaboration of the polity, first as chiefdoms and then as early administrative states. Political actors begin to set uniquely political goals, acquire distinct political tasks, and begin to structurally_-in terms of a growing administration and hierarchy of authority_and symbolically become autonomous. Though often acting with conservative intentions, autonomous polities become progressive forces (Eisenstadt 1963), encourages the growth of autonomy in other institutions, and begins the long, and still not complete, task of separating social action and structure from the ascriptive or kin-based bonds that have marked much of social history.

While population size and density, geographic circumscription, and emergent political autonomy are key variables, a fourth variable deserves as much attention: economic surplus. Economic surplus feeds back on population size, allowing growth in population, as well as supporting the emergence of urban populations that are inherently dense. It also provides the vital resource transforming the polity into a progressive force: once the ruling elite has consistent access to disposable economic surplus, the demand for goods and services accelerates at an unprecedented pace (Lenski 1966). This phenomenon, in and of itself, circulates valued resources like wealth, prestige, and power to newly emergent religious and economic positions, and later, legal and educational.

While this discussion has looked closely at the macro forces responsible for the historical evolution of institutional autonomy, they are still relevant conditions for contemporary analyses. Wherever population size and density is limited; where political 
autonomy is unstable, nonexistent, or overly coercive; or the economic surplus is (a) underdeveloped or (b) overly centralized, institutional autonomy is likely to be low in all institutions except, perhaps, the kinship, polity, and religious institutions.

Micro Forces. The most important force on the micro level conditioning the emergence of institutional autonomy resides in an “entrepreneurial carrier strata,” or a corporate unit acting purposively to secure their own independence in their practices, access to resources to maintain that independence, and control over the transmission of their knowledge and practices to future members (Eisenstadt 1980; Weber 1978). Thus, groups with sole access to key types of knowledge expressed through distinct practicessuch as writing (Eisenstadt 1986; Goody 1986)—have historically been the most important engineers of autonomous institutions. The more valuable—real or perceivedthe knowledge and practices, the greater is their potential power and influence over the society and its members. To be sure, as there are six universal institutions, and few more contemporary ones, certain types of knowledge have been historically privileged over others. For example, nascent autonomous polities have always emerged around leaders and their inner circles, who have demonstrated unique skill in mobilizing social power to wage wars, build massive monuments or public works, energize the community, and/or have seemingly brought or insured economic prosperity. Other institutions have similar stories: law became autonomous through the efforts of a growing legal profession that monopolized the production and distribution of justice and conflict resolution; the economy has been developed through corporate, merchant, and entrepreneurial monopolization of the production and distribution of capital and material subsistence; 
more contemporarily, doctors monopolized the production and distribution of health care and medicine (Starr 1982). ${ }^{\mathrm{i}}$

Thus, wherever entrepreneurial carrier groups seek to, and successfully, organize the material and symbolic resources necessary to produce and distribute certain primary goods and services, the probability that institutional autonomy will emerge increases. However, a few other micro dynamics are at play. The first involves power relations: new carrier groups require (a) access to the necessary resources to sustain their operations, (b) a legitimate monopoly over the application, development, and transmission of their operations - as well as the sole authority to choose future members, and (c) the ability to create institutionally-specific authority structures, with distinct mechanisms of control, that are viewed as legitimate systems of authority by both members of the institution and those outside of the institution.

A third, and highly related dynamic, involves the construction of roles that transcend individual role players, or diffuse generalized roles. The first set of such roles emerges early in hunter/gatherer societies: parent-child and husband-wife. The key criteria for such roles is (1) accessibility by most people, (2) a general understanding of the basic expectations and obligations associated with the role and its counter, and (3) a set of actions, attitudes, and sanctions should the expectations and obligations be violated. ${ }^{\mathrm{j}}$ Moreover, the emergence of diffuse generalized roles allows for social and economic exchange on much high levels of abstraction, an important precondition to the growth of institutional autonomy, where interaction is often abstract and symbolic involving the transfer of intangible resources. All autonomous institutions have these roles, and they are typically organized around status positions. 
The 'ruler' and 'ruled' role-set are a perfect example. A problem that all rulers, whether king or president, must solve is how to 'connect' with the people and gain enough loyalty, commitment, and sacrifice_-often in terms of taxes—-to rule 'effectively.' The people, in turn, must be able to take, respectively, the role of 'subject' or 'citizen' which involves an indirect exchange relationship with the king or president: in exchange for loyalty, commitment, and material support, the ruler provides many intangible services or goods. First, he or she becomes responsible for the continued material prosperity of the group, thus assuming the risk for the community and providing an easy target in cases of famine or recession; second, the king or ruler becomes a totem or symbol of the group which brings pride and hope to human misery: he or she becomes the war hero that legends are written about—i.e., from Gilgamesh to Washington- the paternal or maternal figure, redistributing some wealth, building public goods, and/or the wise man like Solomon passing protective laws; finally, the ruler assumes responsibility for protection and security, both internally and externally. Urban environments especially, become internally divided because of stratification as well as externally targeted because of their encroachment of farm and grazing land through growth; both problems create instability in everyday life, which chiefs, kings, and presidents must resolve through various means. To be sure, this example can be applied to all other institutions: the clergy and the laity; producers and distributors and consumers; lawyers and clients; artists and patrons; doctors and patients; professors and students. The key to these roles, as opposed to others, is they are diffuse in terms of being society-wide, generalized in the sense that from a young age, through socialization, most members of society learn about them and will likely have a chance to play one or both. 


\section{DIMENSIONS OF INSTITUTIONAL AUTONOMY}

Variation in autonomy can have important affects on actors embedded within the institution because it is likely to alter the larger structure that provides the environment in which actions are planned, choices are made, and goals are set. Thus, measuring the variance in institutional autonomy has some important advantages. First, it allows for the comparison of particular institutions across societies at a given time or historically, and how this affects the structure of those societies. For example, one could look at the level of autonomy in political institutions across various historical states and note how increases or decreases in autonomy affected the expansion or contraction of other institutions. Secondly, variance can occur within a given institution, having important intra-societal affects. The U.S. Supreme Court symbolized the growing autonomy of the legal institution when Justice Marshall used judicial review in 1803 (see Marbury v. Madison), effectively striking down legislation for the first time in the history of law (Smith 1996); thirty years later, a change in personnel (enter Justice Taney), as well as a change in the level of autonomy in other U.S. institutions reduced the level of autonomy in the legal institution, which was subsequently restored to much greater levels than ever before during the Warren court (Irons 1999). Thus, autonomy is strongly related to the personnel within the institution, the personnel in extra-institutional positions, and other social forces - the point being, autonomy is tenuous process, characterized by struggle between and within groups. Finally the variation in autonomy can be used to offer descriptive analyses of single states or political units, noting which institutions are more autonomous than others, and then explaining what impact this has on the structure and organization of the given society. 
Five dimensions of institutional autonomy are delineated below. These are all interconnected, thus the greater the degree of all of them, the greater the degree of institutional autonomy. However, they are independent of each other allowing for uneven development of institutional autonomy; changes in any one of them will have different effects on the way autonomy looks. The first three are directly related to the relationships between positions within the institution: in many ways, institutions are simply horizontal and vertical networks of individual and corporate actors. The other two dimensions are key to differentiating institutions from organizations because they deal with symbolic systems.

Breadth. Tilly (2007), in his brilliant analysis of democracy, notes that one measure of the degree of democracy can be found in how deep the relationship between the state and groups in civil society are—do people feel committed to their 'citizen' role and act as such, or is citizenship, as a role, limited to certain groups of people? This can be expanded to elucidate the dynamics of all institutions. As noted above, the construction of elite roles requires counter-roles, or those who recognize the elites legitimate claim and exchange intangible resources like commitment and loyalty, as well as more tangible resources like material wealth. All of these role positions indicate an abstract, indirect system of exchange that sustains distinct system of authority while providing those in subordinate positions with goods and services that satisfy their needs and interests. Thus, breadth reflects the degree to which an institution's symbolic and structural system penetrates other members of society; it addresses the question how many people can potentially orient their behavior towards the values, beliefs, and norms of a given institution and be mobilized. ${ }^{\mathrm{k}}$ The key here is that most people, even those 
actively rejecting the role, know and understand the basic general duties and expectations of the role in relationship to some other diffuse and generalized counter-role. The first proposition can be derived from this discussion: the larger is the number of individual and corporate actors socialized in diffuse generalized institutional positions, the greater is the degree to which an institution will be autonomous.

Monopolization and Legitimation. The monopolization of the material and symbolic resources necessary to reproduce an institutional core is deeply entwined with the level of legitimacy conferred on a group. Nearly all carrier groups must secure the legitimacy of extant elites and the commoners, using this leverage to marginalize their competition. Legitimacy becomes easiest to secure when a carrier group monopolizes certain goods and services that are valued and desired by other groups, thus gaining a power-dependence advantage (Blau 1964). Indeed, history is littered with the remains of struggles and conflicts between carrier groups vying for scarce positions with the winning group most effectively securing legitimacy and monopolizing their practices and knowledge. It is proposed, then, that the greater is the degree to which access, production, distribution, and development of institutional resources are monopolized by a particular corporate or individual actor, the greater is the likelihood that elites and other actors will be dependent upon the goods and services provided by the monopolizing group, which in turn, increases the likelihood that this group will gain legitimate authority over these resources, and therefore, independence in their practices and knowledge. ${ }^{1}$

Before moving on, it is worth looking at the relationship between the first two propositions. The generalized diffuse roles found in the first proposition are often a 
result of the monopolization of certain goods and services on the part of the carrier groups. For example, patients only become patients when doctors are clearly defined, as are their actions and obligations. The roles become diffuse for two reasons. First, the elites that grant legitimacy to the doctors, uses their own authority to embed doctorpatient exchanges into the general socialization of commoners, making it 'normal' to seek 'expert advice' (Starr 1982). This occurs because doctors and other elites enter into worthwhile exchange. On one hand, elites vouch for doctors, providing them with sufficient resources to best the competition, while on the other hand, doctors offer a good and service invaluable to elites: care that prolongs the life and health of its citizen, keeping them happy and helping to sustain the social order. Second, as Collins (2004) notes diffusion is an organic process born out of repeated exchanges that produce positive affect. Indeed, a positive interaction with a doctor is more likely to produce another, as well as more likely to spread by word of mouth to others in the patient's network.

Conflict-Competition. A third dimensions addresses questions of conflict and struggle. Stability and institutional continuity depend on conflict being institutionalized in terms of legitimate rules of engagement and appropriate channels for conflict resolution. It is not that an institutional core is free from contention or that a single institutional logic exists, but rather that contention or the struggle for symbolic hegemony within and between groups must be regulated. Thus, institutions are arenas of conflict because they organize and (unevenly) distribute valued resources, including positions that have access to these resources. However, autonomy is a function of the degree to which conflict is institutionalized within the institutional core. This implies that formal channels for grievances exist, status conflict and political maneuver are limited in terms 
of the possible means that can be employed in these struggles, and finally, even those trying to change the core or usurp the group that has disproportionate access to key positions is not seeking to destroy the structure but gain control of it. The third proposition states that the greater is the degree to which conflict is institutionalized into competition, the greater is the degree to which an institution will be autonomous.

Symbolic Closure. Symbolic closure, or the degree to which an institution has a discrete symbolic or cultural system, is a key dimension of institutional autonomy. The ancient Hebrews, for instance, had a religious system that doubled as a legal and educational system, as well as interacted in important ways with the political system—at least when they composed a political territory (Falk 1964); the Hebrew Bible, or the Torah, was the text that structured and symbolized all of these institutions. The core of the religious institution was bounded more so than the other institutions, and as such, law, education, and in many ways politics, were beholden to religious values, beliefs, and norms. Essentially, the religious core was symbolically bound, while other institutions that were embedded within the religious environment were less bound. Law was given in Leviticus; education was the primary function of the shul (which has become the synagogue in modern Jewish communities), where adult male Jews would learn to read and study the Torah; and the kings all depended upon theocratic legitimacy (Liverani 2005).

It must be remembered that autonomy is never "total," and, therefore, there will always be actors, organizations, buildings, and symbols that are 'borrowed' or imposed on them from other institutional domains. For instance, in most Capitalist societies the business suit is both a material and symbolic resource denoting the economic institution, 
but has become a pervasive form of 'professional' attire regardless of the institution that an actor finds him or herself most embedded within. Admittedly, the economic institution, as well as the polity, often penetrates other institutional cores limiting the level of potential autonomy attainable; while this may appear to be a weakness of the theory being proposed, it must be remembered that the interesting thing about autonomy is the process itself and not the finished state. To put it another way, the economy and polity are often important arenas of struggle, and they also have important effects on the autonomy of other institutions. But, this is neither constant nor guaranteed. Rather, the polity's influence over the legal system, for example, can fluctuate based on a number of factors. It would be difficult to argue that the Warren court was being controlled or was subordinate to the polity or the economic system. Rather, the justices on that court were determined to change the social structure around them, often at the behest of other institutional domains, their constituent actors, and their prerogatives. Thus a fourth proposition can be derived: the greater the degree to which an institution is symbolically bound, the greater the degree to which an institution will be autonomous.

Symbolic Media and Marketplace Dynamics. Parsons (1951) was perhaps the most important advocate of the concept generalized symbolic media of exchange (see also Luhmann 1982; Simmel 1907). Essentially, Parsons understood institutions to be marketplaces of social exchange. They existed because humans interacted with each other, derived useful, desired, and necessary goods and services that through frequently repeated exchange created external systems of action; these systems of action became 'marketplaces' of social exchange. However, when heterogeneity increases, exchange and interaction becomes increasingly difficult, and some media of exchange must emerge 
that is generalizable enough to reduce uncertainty and risk while facilitating a myriad of exchanges. Money, of course, is the classic example of this social construction. Parsons, though, made the important distinction that money was the primary mechanism of exchange in a symbolically bounded economy, meaning that other institutions that were symbolically closed or bounded necessitated other forms or media of exchange.

While it is not out of the question for institutions to develop more than one media of exchange, each historically universal institution, when autonomous, has had domain over one particular media of exchange, while others may emerge to facilitate certain kinds of exchanges (see Table 1 for a complete list). These media further reinforce the symbolic and structural boundedness of the institution by limiting the types of exchange, the styles in which these exchanges can take place, and the appropriate return on the exchange (Luhmann 1984). Moreover, they provide the goods and services that extrainstitutional actors seek which ultimately reproduce the institution and its constituent actors.

This point can be further illustrated using the autonomous legal institution, which typically uses justice as it medium of exchange (Chayes 1988; Lloyd 1964). Justice is universally desired in all societies, regardless of the variation in terms of what justice means and how it is procured. As society becomes increasingly complex and conflicts and their resolution grow concomitantly, the legal institution increasingly becomes the central location for conflict resolution. As such, it ‘deals' in justice as defined by the social milieu. In a highly differentiated society, an autonomous legal institution exchanges justice for other media like money—-through clients using the legal system to establish or procure justice — or power-through the polity legitimating an independent 
judiciary as being an equal, but separate branch and providing the coercive force necessary to back legal decisions.

It also shapes the themes, texts, and interactions between those cognitively oriented towards the legal institution (Luhmann 2004). Because justice becomes a medium of exchange, it is a highly valued resource that is contested and struggled for. This implies that its meaning will often be finitely different depending upon the faction or strata one belongs to. However, when legal roles become generalized and diffuse, a group of actors monopolize legal resources and conflict resolution, and what justice means becomes institutionalized and bound, the legal institution will likely become autonomous and interactions within the institution and with other institutions will involve 'justice'. This however does not devalue the importance of generalized media, but rather it explicates its value because control over the production and distribution of the medium is the goal of groups, and not its destruction. Thus our fifth proposition can be derived: the greater the degree to which the generalized medium of exchange facilitating and constraining institutional interchanges and institution-specific social exchange, the greater the degree to which an institution will be autonomous.

\section{CONCLUSION}

I started out by admiring the important contributions that the functionalist and neoinstitutional school has provided in terms of organizational dynamics, while noting the limitations of the both schools' conceptualizations of institutions. As an alternative, I proposed a theoretical framework that analyzes institutional evolution as an emergent process built on the efforts and struggles of certain corporate units. What was proposed is not entirely new, but rather a synthesis of extant literature in hopes of providing the 
neoinstitutionalists and the remaining functionalists with another level of institutional analysis to consider. In doing so, two tasks could be addressed: first, processes long ignored by functionalists could be addressed more precisely and second, a more robust institutional environment could be provided to supplement the organizational dynamics brilliantly delineated by the neoinstitutional school.

Ultimately I have argued that institutional autonomy is the key institutional dynamic affecting the way societies are structured and the types of actions that are likely to result. Autonomy is variable in terms of time and place. Moreover, its variability reflects the very real struggles that corporate and individual actors engage in everyday to maintain the foothold that they have in the horizontal and vertical systems that they find themselves. Changes in personnel, shocks to the system, and social movements are some of the independent variables that can radically alter the institutional complex in a given society, altering the level of autonomy of a given institution or all institutions. Finally, institutional autonomy—in terms the amount of autonomy that all institutions have as well as which institutions are most autonomous — will have important effects on structure and action: it will define the boundaries and limits of human and societal potential. The next steps in the construction of a general theory of institutional autonomy will be to elucidate these general principles systematically through applications to historical cases and the comparative perspective. The contribution of this paper was to delineate the five dimensions of institutional autonomy, examine the generic forces causing autonomy, and discuss the relevance of a theory of institutional autonomy in regards to the functionalist and neoinstitutional traditions. 


\section{REFERENCES}

Akhavi, Shahrough. 1992. "The Clergy's Concepts of Rule in Egypt and Iran." Annals of the American Academy of Political and Social Science 524:92-102.

Alexander, Jeffrey C. and Paul Colomy. 1990. "Differentiation Theory and Social Change: Comparative and Historical Perspectives." New York: Columbia University Press.

Baker, Henry E. 1968. The Legal System of Israel. Jerusalem: Israel University Press.

Barak, Aharon. 2000. "Some Reflections on the Israeli Legal System and Its Judiciary." in Conference of the Ius Commune Research School. Leuven.

Berman, Harold J. 1955. "The Law of the Soviet State." Soviet Studies 6:225-37.

—. 1968. "The Soviet Legal Profession." Harvard Law Review 82:1-41.

- 1983. Law and Revolution: The Formation of the Western Legal Tradition, vol. I. Cambridge, MA: Harvard University Press.

Black, Donald. 1976. The Behavior of Law. San Diego: Academic Press.

Blau, Peter M. 1964. Exchange and Power in Social Life. New Brunswick: Transaction Publishers.

—. 1970. "A Formal Theory of Differentiation in Organizations." American Sociological Review 35:201-18.

Bohannan, Paul. 1967. "Law and Warfare: Studies in the Anthropology of Conflict." Garden City, NY: Natural History Press.

Boserup, Ester. 1965. The Conditions of Agricultural Growth: The Economics of Agrarian Change under Population Pressure. Chicago: Aldine Publishing.

Brint, Steven. [1998] 2006. Schools and Societies. Stanford: Stanford University Press.

Carlin, Jerome E. 1980. "Lawyers' Ethics." Pp. 257-67 in The Sociology of Law: A Social-Structural Perspective, edited by W. M. Evan. New York: The Free Press.

Carneiro, Robert L. 1970. "A Theory of the Origin of the State." Science 169:733-38.

Chang, Kwang-chih. 1983. Art, Myth, and Ritual: The Path to Political Authority in Ancient China. Cambridge: Harvard University Press.

Chayes, Abram. 1988. "How Does the Constitution Establish Justice?" Harvard Law Review 101:1026-42.

Collins, Randall. 1979. The Credential Society: An Historical Sociology of Education and Stratification. New York: Academic Press.

—. 2004. Interaction Ritual Chains. Princeton: Princeton University Press.

Colomy, Paul and Gary Rhoades. 1994. "Toward a Micro Corrective of Structural Differentiation Theory." Sociological Perspectives 37:547-83.

Comte, Auguste. [1851-4] 1968. System of Positive Polity, vol. 1-4. New York: Burt Franklin.

Diamond, Jared. 2004. Collapse: How Societies Choose to Fail or Succeed. London: Viking Adult.

DiMaggio, Paul. 1991. "Constructing an Organizational Field as a Professional Project: U.S. Art Museums, 1920-1940." Pp. 267-92 in The New Institutionalism in Organizational Analysis, edited by W. W. Powell and P. DiMaggio. Chicago: University of Chicago Press. 
DiMaggio, Paul and Walter W. Powell. 1983. "The Iron Cage Revisited: Institutional Isomorphism and Collective Rationality in Organizational Fields." American Sociological Review 48:147-60.

Dobbin, Frank and John R. Sutton. 1998. "The Strength of a Weak State: The Rights Revolution and the Rise of Human Resources Management Divisions." American Journal of Sociology 104:441-76.

Douglas, Mary. 1970. Natural Symbols: Explorations in Cosmology. New York: Pantheon Books.

Durkheim, Emile. 1893. The Division of Labor in Society. Translated by W. D. Halls. New York: The Free Press.

- 1895. The Rules of Sociological Method and Selected Texts on Sociology and its Method. Translated by W. D. Halls. New York: Free Press.

Edelman, Lauren B. and Mark C. Suchman. 1997. "The Legal Environments of Organizations." Annual Review of Sociology 23:479-515.

Eisenstadt, S.N. 1963. The Political System of Empires: The Rise and Fall of the Historical Bureaucratic Societies. New York: Free Press.

—. 1964. "Social Change, Differentiation and Evolution." American Sociological Review 29:375-86.

—. 1965. "Essays on Comparative Institutions." New York: John Wiley \& Sons.

—. 1980. "Cultural Orientations, Institutional Entrepreneurs, and Social Change: Comparative Analysis of Traditional Civilizations." American Journal of Sociology 85:840-69.

—. 1986. "The Origins and Diversity of Axial Age Civilizations." Albany: State University of New York Press.

Englard, Izhak. 1974. "The Law of Torts in Israel: The Problem of Common Law Codification in a Mixed Legal System." American Journal of Comparative Law 22:302-29.

Fagan, Brian. 2004. The Long Summer: How Climate Changed Civilization. New York: Basic Books.

Falk, Ze'ev. 1964. Hebrew Law in Biblical Times: An Introduction. Jerusalem: Wahrmann Books.

Fox, Robin. 1967. Kinship and Marriage: An Anthropological Perspective. London: Cambridge University Press.

Freidson, Eliot. 1994. Professions Reborn: Theory, Prophecy, and Policy. Chicago: University of Chicago Press.

Fried, Morton H. 1967. The Evolution of Political Society. New York: Random House.

Gat, Azar. 2006. War in Human Civilization. Oxford: Oxford University Press.

Giddens, Anthony. 1984. The Constitution of Society. Berkeley: University of California Press.

Gluckman, Max. 1965. Politics, Law and Ritual In Tribal Society. Chicago: Aldine.

Goffman, Erving. 1959. The Presentation of Self in Everyday Life. New York: Anchor Books.

—. 1961. Asylums: Essays on the Social Situation of Mental Patients and Other Inmates. Garden City, NY: Anchor Books.

Goode, William J. 1951. The Religion Among the Primitives. Glencoe, Il: Free Press. 
Goody, Jack. 1986. The Logic of Writing and the Organization of Society. Cambridge: Cambridge University Press.

Hannan, Michael T. and John Freeman. 1977. "The Population Ecology of Organizations." American Journal of Sociology 82:929-64.

Harries, Jill. 1999. Law \& Empire in Late Antiquity. Cambridge: Cambridge University Press.

Hawley, Amos H. 1986. Human Ecology: A Theoretical Essay. Chicago: University of Chicago Press.

Hirschfield, Robert S. 1965. The Constitution and the Court. New York: Random House. Hoebel, E. Adamson. 1973. The Law of Primitive Man. New York: Antheneum. Homans, George C. 1950. The Human Group. New York: Harcourt, Brace \& World. Irons, Peter. 1999. A People's History of the Supreme Court: The Men and Women Whose Cases and Decisions Have Shaped Our Constitution. New York: Penguin Books.

Jepperson, Ronald L. 1991. "Institutions, Institutional Effects, and Institutionalism." in The New Institutionalism of Organizational Analysis, edited by W. W. Powell and P. J. DiMaggio. Chicago: The University of Chicago Press.

Johnson, Allen W. and Timothy Earle. 2000. The Evolution of Human Societies: From Foraging Groups to Agrarian State. Stanford: Stanford University Press.

Kunkel, Wolfgang. 1966. An Introduction to Roman Legal and Constitutional History. Translated by J. M. Kelly. Oxford: Oxford University Press.

Lenin, V.I. [1917] 1976. The State and the Revolution. Peking: Foriegn Languages Press.

Lenski, Gerhard. 1966. Power and Privilege: A Theory of Social Stratification. New York: McGraw-Hill.

—. 2005. Ecological-Evolutionary Theory. Boulder: Paradigm.

Levi-Strauss, Claude. 1969. The Elementary Structures of Kinship. Translated by J. H. Bell, J. R. von Strumer, and R. Needhan. Boston: Beacon Press.

Liverani, Mario. 2005. Israel's History and the History of Israel. Translated by C. Peri and P. R. Davies. London: Equinox.

Lloyd, Dennis. 1964. The Idea of Law. Baltimore, MA: Penguin Books.

Luhmann, Niklas. 1982. The Differentiation of Society. New York: Columbia University Press.

—. 1984. Social Systems. Translated by J. Bednarz Jr. and D. Baecker. Stanford: Stanford University Press.

—. 2000a. Art as a Social System. Translated by E. M. Knodt. Stanford: Stanford University Press.

-. 2000b. The Reality of Mass Media: Cultural Memory in the Present. Stanford: Stanford University Press.

—. 2004. Law as a Social System. Translated by K. A. Ziegert. Oxford: Oxford University Press.

Malinowski, Bronislaw. 1959. Crime and Custom in Savage Society. Paterson, NJ: Littlefield, Adams, and Co.

Malthus, Thomas. [1798] 1926. First Essay on Population. New York: Kelley.

Maryanski, Alexandra and Jonathan H. Turner. 1992. The Social Cage: Human Nature and the Evolution of Society. Stanford: Stanford University Press.

Merton, Robert K. 1938. "Social Structure and Anomie." American Sociological Review 3:672-82. 
Meyer, John W. 1987. "The World Polity and the Authority of the Nation-State." Pp. 4170 in Institutional Structure: Constituting State, Society and the Individual, edited by G. M. Thomas, J. W. Meyer, F. Ramirez, and J. Boli. Newbury Park, CA: Sage.

Meyer, John W. and Brian Rowan. 1977. "Institutionalized Organizations: Formal Structure as Myth and Ceremony." American Journal of Sociology 83:340-63.

Michels, Robert. [1911] 1962. Political Parties: A Sociological Study of the Oligarchical Tendencies of Modern Democracy. Translated by E. Paul and C. Paul. New York: Free Press.

Nee, Victor. 2005. "The New Institutionalisms in Economics and Sociology." in The Handbook of Economic Sociology, edited by N. J. Smelser and R. Swedberg. Princeton: Princeton University Press.

North, Douglass C. 1990. Institutions, Institutional Change, and Economic Performance. Cambridge: Cambridge University Press.

Parsons, Talcott. 1951. The Social System. Glencoe, Ill.: Free Press.

—. 1990. "Prolegomena to a Theory of Social Institutions." American Sociological Review 55:319-33.

Parsons, Talcott and Neil J. Smelser. 1956. Economy and Society: A Study in the Integration of Economic and Social Theory. New York: The Free Press.

Polanyi, Karl. 1944. The Great Transformation: The Political and Economic Origins of Our Time. Boston: Beacon Press.

—. 1957. "The Economy as Instituted Process." in Trade and Market in the Early Empires: Economies in History and Theory, edited by K. Polanyi, C. M. Arensberg, and H. W. Pearson. Glencoe, Ill: Free Press.

Popper, Karl. [1934] 2002. The Logic of Scientific Discovery. London: Routledge.

Postgate, J.N. 2003. Early Mesopotamia: Society and Economy and the Dawn of History. New York: Routledge.

Potts, D.T. 1997. Mesopotamian Civilization: The Material Foundations. Ithaca: Cornell University Press.

Powell, Walter W. and Paul J. DiMaggio. 1991. The New Institutionalism in Organizational Analysis. Chicago: The University of Chicago Press.

Rueschemeyer, Dietrich. 1977. "Structural Differentiation, Efficiency, and Power." American Journal of Sociology 83:1-25.

Sanderson, Stephen K. 2007. Evolutionism and Its Critics: Deconstructing and Reconstructing an Evolutionary Interpretation of Human Society. Boulder, CO: Paradigm.

Schirazi, Asghar. 1997. The Constitution of Iran: Politics and the State in the Islamic Republic. Translated by J. O'Kane. London: I.B. Taurus Publishers.

Scott, W. Richard. 2001. Institutions and Organizations. Thousand Oaks, CA: Sage. Service, Elman R. 1962. Primitive Social Organization: An Evolutionary Perpective. New York: Random House.

-. 1971. Profiles in Ethnology. New York: Harper \& Row.

- 1975. Origins of the State and Civilization: The Process of Cultural Evolution. New York: W.W. Norton \& Company.

Simmel, Georg. 1907. The Philosophy of Money. Boston: Routledge \& Kegan Paul. 
Smith, Jean Edward. 1996. John Marshall: Definer of a Nation. New York: Henry Holt and Company.

Spencer, Herbert. 1874-96. The Principles of Sociology. New York: Appleton.

Starr, Paul. 1982. The Social Transformation of American Medicine: The Rise of the Sovereign Profession and the Making of a Vast Industry. New York: Basic Books, Inc.

Stryker, Sheldon. 1980. Symbolic Interactionism: A Social Structural Version. Menlo Park, CA: The Benjamin Cummings Publishing Company.

Sutton, John R. and Frank Dobbin. 1996. "The Two Faces of Governance: Responses to Legal Uncertainty in U.S. Firms, 1955 to 1985." American Sociological Review 61:794-811.

Swidler, Ann. 1986. "Culture in Action: Symbols and Strategies." American Sociological Review 51:273-86.

Tadmor, Hayim. 1986. "Monarchy and the Elite in Assyria and Babylonia: The Question of Royal Accountability." Pp. 203-26 in The Origins and Diversity of Axial Age Civilizations, edited by S. N. Eisenstadt. Albany: State University of New York Press.

Tilly, Charles. 2007. Democracy. Cambridge: Cambridge University Press.

Turner, Jonathan H. 2003. Human Institutions: A Theory of Societal Evolution. Lanham: Bowman \& Littlefield Publishers, Inc.

Turner, Ralph H. 2001. "Role Theory." in Handbook of Sociological Theory, edited by J. H. Turner. New York: Kluwer Academic/Plenum Publishers.

Unger, Roberto M. 1976. Law In Modern Society: Towards a Criticism of Social Theory. New York: Free Press.

Weber, Max. 1922. The Sociology of Religion. Translated by T. Parsons. Boston: Beacon Press.

-. 1967. Max Weber on Law in Economy and Society, Edited by M. Rheinstein. Translated by E. Shils and M. Rheinstein. New York: Simon and Schuster.

-. 1978. Economy and Society: An Outline of Interpretive Sociology, vol. 1-2, Edited by G. Roth and C. Wittich. Berkeley: University of California Press.

Yoffee, Norman. 2005. Myths of the Archaic State: Evolution of the Earliest Cities, States, and Civilizations. Cambridge: Cambridge University Press. 
${ }^{a}$ It is worth noting that there is a literature that has begun to address this deficiency (e.g., Colomy and Rhoades 1994; Eisenstadt 1980). Unfortunately, it has been relegated to the margins of general sociology with the other work done that finds its roots in the classic tradition.

${ }^{\mathrm{b}}$ These lists, of universal and newer institutions, should not be taken as definitive. Science is a cumulative endeavor and I am fully prepared to add and subtract from this list.

' To be sure, this definition is oriented to macro level institutions and not "proto-institutions" or, as Eisenstadt (1965) refers to them "partial-institutions" such as "the handshake," "voting," or other ritualized micro/meso level action (Jepperson 1991). Admittedly, this is a limitation of the theory posited below, but institutional autonomy is a macro level dynamic having implications for meso and micro level behavior and attitudes; moreover, while it is neither time nor the place to elaborate upon the distinction between the two (for a good discussion of these differences, see Eisenstadt 1965), there may be benefit in seeing these more micro or meso level patterns of action as being mechanisms of institutional control rather than institutions akin to the polity or law (Polanyi 1957).

${ }^{\mathrm{d}}$ Autonomy is neither guaranteed nor inevitable; rather it reflects a universal process that has historically occurred in the process of socio-cultural evolution, societal growth, and the increase in complexity. Dedifferentiation and uneven development of institutional autonomy are processes that are just as likely to occur given the tenuous nature and improbability of social life (Rueschemeyer 1977). Finally, these macro forces are one side of the process: real actors construct and maintain institutions, not anonymous forces. ${ }^{\mathrm{e}}$ It must be remembered, though, that the niche or the organizational field is embedded within a larger institutional context. Thus, corporate units select some elements and not others in constructing their structural and symbolic boundaries; the selection process accounts for the variation in form and content across an entire society. Nevertheless, the number and type of elements are not infinite implying constraint on the corporate unit in many different ways.

${ }^{\mathrm{f}}$ Incidentally, once an institution becomes autonomous in one location, the gradual process of autonomy is mitigated through diffusion. Similarly, John Meyer (1987) notes that the nation-state, arduously constructed, becomes a "cultural blueprint" that can be borrowed, modified, and adapted by other polities once it exists and can become diffuse.

${ }^{\mathrm{g}}$ To be sure, not all judges all the time are guided by ideals of justice because law, like all other institutions, can never be completely or truly autonomous. Rather, it varies and so does the actors orientations.

${ }^{\mathrm{h}}$ It should be noted that I do not assume that $a$ value-system exists in a given institution, or for that matter, any monolithic symbolic set. Typically, there is a dominant value-system that actors have uneven access to, and are unevenly committed to-which is why institutions do not simply rely on normative commitment to establish and maintain social control. As Bourdieu has correctly argued, institutions are arenas of struggle, predominantly over the "legitimate vision of reality."

i I use the term 'monopoly' much like Weber: it does not imply total possession, but rather majority possession.

${ }^{\mathrm{j}}$ This is not to say that all mothers are identical. Indeed, there is a degree of wiggle room for all roletaking, and each mother varies based on personality, historical and social context, and other external factors.

${ }^{\mathrm{k}}$ To be sure, not all members of a society will (a) actively or have the ability to play a role such as 'citizen', (b) be motivated or committed to the role in question, or (c) be aware of the duties. Moreover, rejection, rebellion, or illegitimate role-playing are all potential patterns of action, but even these often follow some type of proscribed pattern of norms (Merton 1938).

${ }^{1}$ Again, autonomy is variable. In the United States, for example, judges are not selected by other judges or lawyers, but rather by politicians. However, in the Israeli legal system, a group of lawyers and extant judges select new members. The key is that it is variable, and autonomy is not simply determined and reflected by one dynamic, but by the additive properties of all five. 